\title{
History of Weeds in Western Canada
}

\author{
by the late A. C. Budd
}

EDITOR'S NOTE: The following article, not previously printed, is almost exactly as it was given by $\mathrm{Mr}$. Budd in addresses to the Weed Innspectors and Supervisors Course in Saskatoon in 1952 and 1953. Mr. Budd, who was Range Botanist, Canada Department of Agriculture, Experimental Form, Swift Current, contributed regularly to the Blue Jay till his death. Dr. J. F. Alex, Ecologist, Weed Control Research Station, Canada Department of Agriculture, Experimental Farm, Regina provided the illustrations and kindly edited and combined the two talks given by Mr. Budd on this subject.

What is a weed? It is variously defined in dictionaries as "wild growth, a wild herb springing where it is not wanted, any plant growing in cultivated ground to the detriment of the crop or to the disfigurement of the place, and as an economically useless or unsightly plant." Emerson stated, "a weed is a plant whose virtues have not been discovered." My own definition is that weeds are nature's method of correcting man's mistakes.

Were weeds present in our Prairies before white man settled here and brought the land under cultivation? Yes, many of the plants we now call weeds were here long before the first white man arrived. These included: spearleaf goosefoot, Monolepis nuttaliana (R. and S.) Greene; red goosefoot, Chenopodium rubrum L.; oakleaf goosefoot, C. salinum Standl.; lamb's quarters, C. album L. s.l.; orache, Atriplex spp.; gray and green tansy mustards, Descurainia richardsonii (Sweet) O. E. Schulz and D. pinnata (Walt.) Britt. var. brachycarpa (Richards.) Fern.; branched peppergrass, Lepidium ramosissimum Nels.; spider flower, Cleome serrulata Pursch; the evening primroses, Oenothera spp.; wild tomato, Solanum triflorum Nutt.; false ragweed, Iva xanthifolia Nutt.; giant ragweed, Ambrosia trifida L.; perennial ragweed, A. psilostachya DC.; biennial wormwood, Artemisia biennis Willd.; pasture sage, $A$. frigida Willd.; broomweed, Gutierrezia sarothrae (Pursh) Britt. and Rusby; gumweed, Grindelia squarrosa (Pursh) Dunal; Canada fleabane, Erigeron canadensis L.; the sunflowers, Helianthus spp.; blue lettuce, Lactuca pulchella (Pursh) DC.; and the skeleton weeds, Lygodesmia spp.
Native grasses of the prairies were frequently subjected to overgrazing by roving buffalo herds. In such areas, the scil was exposed to rapid wind and water erosion. With reduced competition from grasses broad-leaved plants (such as pasture sage, broomweed and sunflowers) grew taller, more robust and more numerous than before overgrazing occurred. Their increased growth modified ground winds, held the snow, and reduced excessive run-of of rain. In the protection they afforded, soil erosion was reducec and the grass became re-established In other areas of soil disturbance such as gopher mounds, buffalo wallows and animal trails, annual plant: - like wild tomato and tumbleweec - grew quickly. They were followed by perennials and eventually a return of the native grasses,

Most of these plants still perform the same role they did in past cen. turies; today we call them "weeds" because either we want to maintair the soil in a disturbed condition, os we have other uses for it.

With the advent of white man ir the prairies new weeds appeared Fort Chesterfield was established ir 1822 near Empress, Alberta. A Hud. son's Bay trading post was set up ir 1871 near East End on the Saskatch. ewan side of the Cypress Hills. Bales of trading goods and food stuffs for both man and beast were brought ir and with them the seeds of plant: from distant regions. Knotweed (Polygonum spp.), stinkweec (Thlaspi arvense L.), dandelior (Taraxacum officinale L.), and the sowthistles (Sonchus spp.) invariably became plentiful around the early forts and posts. In 1873-1874 thi Boundary Commission surveyed thi International Boundary, and in 187 Commissioner French brought the first detachment of the Mounter Police through these souther prairies. Both parties carried quan. tities of oats for feeding horses anc oxen as well as their own baggage No doubt many weeds were brough in by this manner from the centra United States and from eastern Can. 
southern part of the Western Canadian Prairies was predominantly ranching country. Prairie fires were a perpetual hazard so systems of long fireguards were ploughed. These were often covered with tumbleweed and tumbling mustard throughout their entire length.

The advent of the homesteader and the growing of grain on a large scale brought about a decided change in the prairie flora. Whereas prairie grass had previously been king, the new annual grasses-wheat, oats and barley-were substituted. The compact and somewhat weed-resistant sod was broken up and rendered very receptive to most forms of plant life. Imponts of seed grain from the older countries brought in many and varied species of European and Asiatic weeds, and until the less hardy species were eliminated by severe climatic conditions a very large number of species could be found. In my first crop for instance, in 1911, the first weed I pulled was a purple cockle, a weed I have never since seen growing wild in Canada.

In 1910, when I homesteaded about 18 miles easit of Swift Current, the few weeds growing in cropped land in the area could generally be pulled on a Sunday and were mostly lamb's quarters. By 1911 the commonest weed in my own crop was wormseed mustard (Erysimum cheiranthoides L.), but there were also numerous plants of false flax, ball mustard, cow cockle, purple cockle and wild buckwheat brought in with the Manitoban seed I used. Of these the only one to persist to any great extent was wild buckwheat which seemed betiter suited to our semi-arid conditions and was more difficult to remove from grain than were the others.

Large acreages were seeded to flax in 1912 and with that crop came numerous weeds, especially the mustardis (Brassica spp.). The moist spring of 1913 was followed by increased prominence of lamb's quarters, tumbling mustard, skeleton weed and wild tomato, the latter two particularly in gardens. Wild buckwheat remained the most plentiful, however, as its seeds were already thoroughly distributed across the farm.

In the Swift Current area 1914 was a dry season and the scanty crops were polluted with tumbling mustard. Because of the shortage of feed for livestock, the government shipped in feed oats and encouraged relief work on road-building. This feed was abominably dirty with wild oats (Avena fatua L.) and stinkweed, and was the major cause of severe infestations of both weeds in subsequent years. Russian thistle (Salsola pestifer A. Nels.) was first seen in our region that fall, being found in road cuts and borrow-pits (places from which soil was "borrowed" to make a high grade). This Eurasian plant had been reported from South Dakota in 1873, Manitoba in 1894 and southern Alberta a few years later. Although by 1914 it had become plentiful in southern Alberta and was rapidly spreading eastward, no warning had been published about it. Practically all the weed propaganda had been directed at perennial sowthistle, a weed we had no need to fear in our dry area.

Steady, cool, drizzling rains during the 1915 growing season followed by a long, open fall gave us the best crops we had ever known. We farmers were too busy crowing over our bumper crops, spending our wheat money and paying our debts to bother about trifles like weeds! Nevertheless, they were present in abundance. In the exposed soil of borrow-pits and road cuts made the previous fall, there was a vast growth of weeds and native plants. Our drab scenery was much brightened by showy plants of spider flower, scarlet mallow (Malvastrum coccineum (Pursh) A. Gray), white and yellow evening primroses, scarlet gaura (Gaura coccinea Pursh), coneflower (Ratibida spp.), goldenrods (Solidago spp.), etc.

1916 was one of those wet and dry years: dry most of the season but with occasional extremely heavy, torrential rains. Lamb's quarters was very luxuriant. Grain and stinkweed grew apace. Canada thistle was abundant along roadsides. Nevertheless, it was during the dry periods of that year that we first experienced soil drifting. The expectations of anather bumper crop were dashed when rust hit the grain and it only yielded five or six bushels of very low grade wheat to the acre.

Then followed the first real run of 


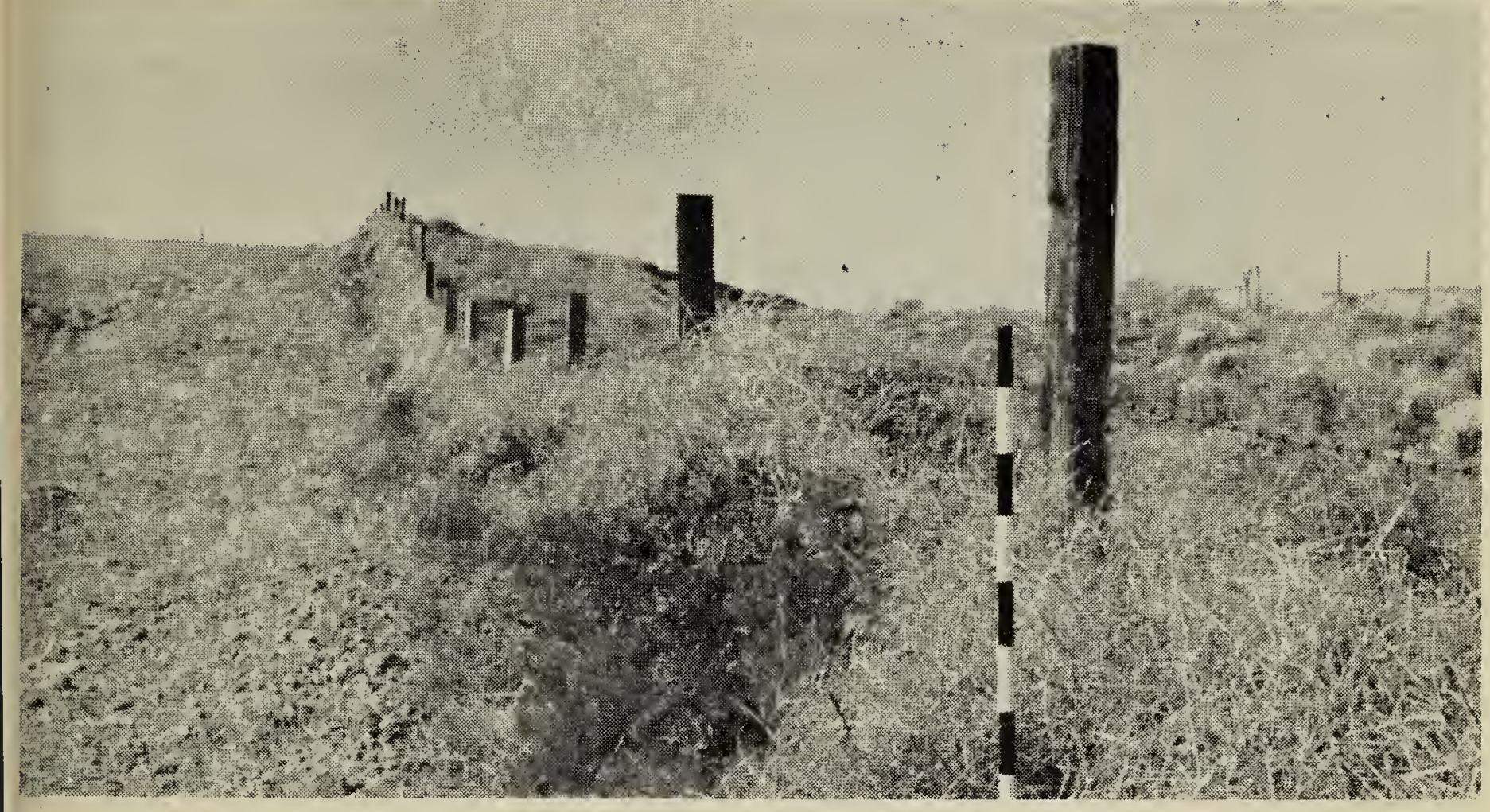

Photo by J. F. Alex.

Had it not been for Russian thistle the south-west might have become a blown-out desert during the dry years since 1914.

dry years-1917, 1918 and 1919when conditions became progressively worse for the farmers. During these years Russian thistle increased immensely. Farmers had been recommended by the authorities to sow their grain at lighter rates. The lighter stand of grain meant many misses and gaps which the weeds occupied. Soil drifting was very bad and the high winds rolled Russian thistle everywhere. Wie cussed it, we damned it and we figured that still another evil had been loosed from Pandora's box to torment us; but really it was a sheep in wolf's clothing and perhaps was the best thing that happened to us. During these drought years it made a tolerable stock feed, not the best by any means, but the stock could get by on it. More important, though, it covered the bare ground with a mat of vegetation and reduced erosion to a minimum. Had it not been for Russian thistle the south-west might have become a blown-out desert. This was the basis of my definition of a weed as, "nature's method of correcting man's mistakes." Since then Russian thistle has been our dominant weed and has sept most other weeds in check. Attempts have been made to get rid ff it but, getting rid of it if successful, might mean that another and naybe worse weed would take its blace.
In a short ten years our countryside had changed from clean, virgin prairie to blocks of cultivated land within a network of roads and railways, all badly infested with weeds.

Many other weeds have become prominent since the early homestead days. Prickly lettuce (Lactuca scariola L.) is now abundant around slough margins and in waste places in towns and villages. Flixweed (Descurainia sophia (L.) Webb), a close relative of the tansy mustards, was introduced from Europe and is now common throughout the prairies, even growing in native grassland wherever a tiny patch of disturbed sod is encountered. Yellow goatsbeard (Tragopogon dubius Scop.), originally introduced from Europe to Colorado as an ornamental garden plant, slowly migrated northward and eastward across the prairies and was first encountered here about 1928. Kochia (Kochia scoparia (L.) Roth) and garden atriplex (Atriplex hortensis L.) are garden plants that have escaped from cultivation and become common in and anound towns throughout the prairies. Hedge bindweed or wild morning glory (Convolvulus sepium L.), a native perennial vine which was occasionally found on bushes along water courses, has spread in cultivated land and become an important weed in many regions of moist soil. Poverty weed 


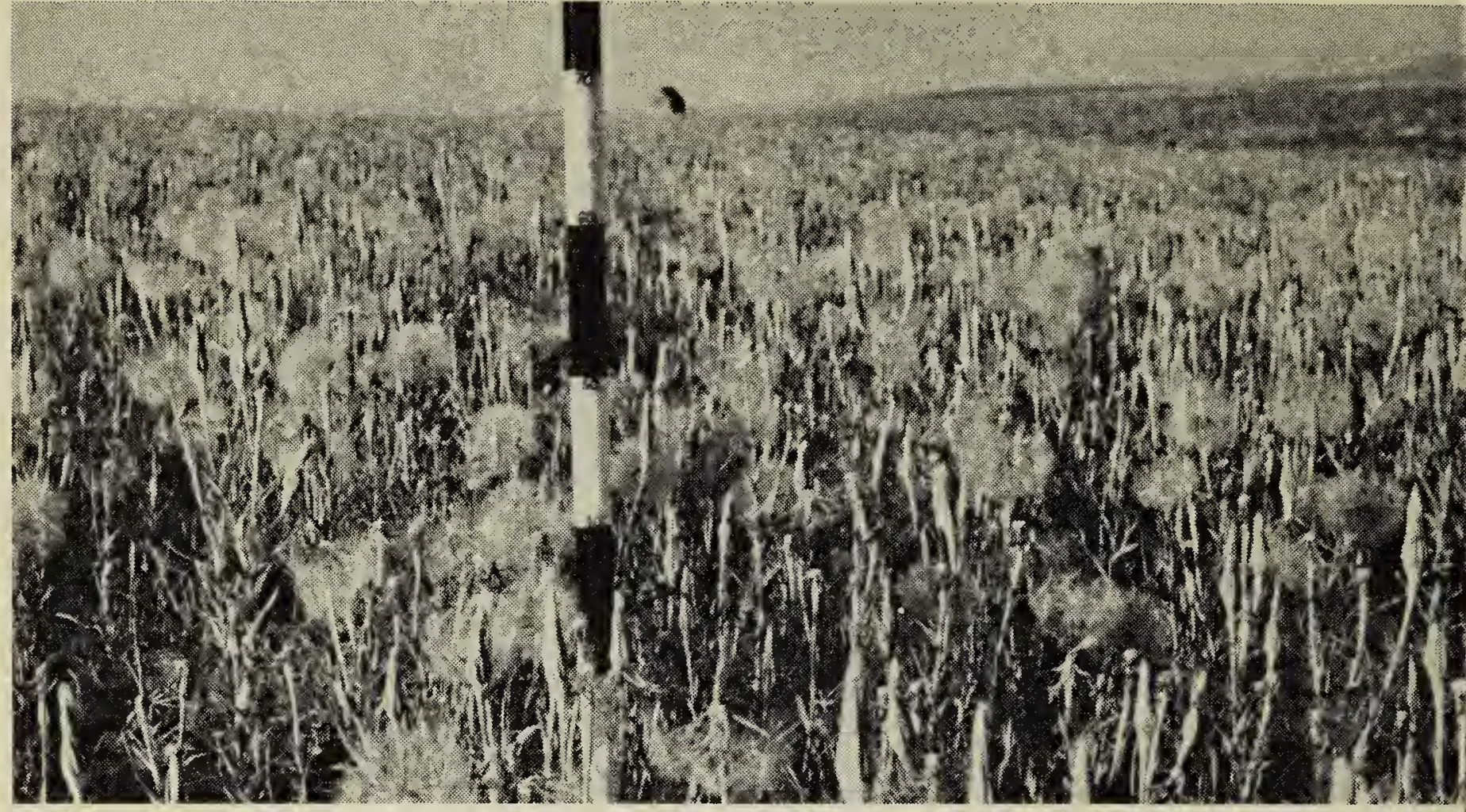

Photo by J. F. Alex

Yellow Goatsbeard reached Western Canada from Europe via Colorado about 1928. In this 100acre abandoned field in southern Alberta it is virtually the sole occupant.

(Iva axillaris Pursh) and several smartweeds (Polygonum spp.) have similarly become troublesome in cultivated fields. These native plants were not aggressive under pristine conditions but they are better adapted to certain soil conditions after cultivation than are the economic plants farmers try to grow.

With settlement, came the planting of introduced trees, small fruits, vegetables, flowers and lawn grasses around homes, as well as new forage plants for improved hay and pasture. These introductions proved to be prolific sources of new weeds, as contaminants either in the seed or occasionally in the packing around roots of nursery plants. Hoary cress (Cardaria spp.), leafy spurge (Euphorbia esula L.), field bindweed (Convolvulus arvensis L.), Russian knapweed (Centaurea repens L.), purslane (Portulaca oleracea L.) and common chickweed (Stellaria media (L.) Cyrill) are examples of weeds introduced in this manner.

Many of our weed problems (nct all, but many) are the result of improper farming methods: land used for the wrong purpose or land improperly worked. Moist soils usually require more tillage than drier ones, yet low areas and slough margins in a field often receive less treatment and consequently grow weeds. Saline areas are often put under cultivation with a resultant weed growth insteac of crop. Many areas of light, dry soi. which should have been left under native grassland were ploughed anc eventually became covered witr Russian thistle, tumbling mustarc and other weeds.

What does the future hold for weeds in Western Canada? Currently most farmers lean upon 2,4-D and other chemical herbicides as thei panacea. Use of these herbicides ma: result in clean fields where mustar and other susceptible species are pre dominant. But will other weeds re place these species? We have noticer in our area that where herbicide have checked Russian thistle becaus it is susceptible, there has been : great increase in wild buckwhea which is resistant. Competition fron Russian thistle had previously re stricted the growth of wild buck wheat but when released from tha competition the wild buckwheat be came much more abundant. Unles accompanied by good husbandm. these chemically-treated fields ma. become the home of resistant specie and the last stage may be worse tha the first. The use of herbicides shoul be considered as supplementary t good husbandry, not as a substitut for it.

Although this may be an heretica thought to raise at a meeting of weer control personnel, I believe there ar 
two sides to the problem of weeds. Weeds are not entirely bad. Nature abhors a vacuum. If we leave the soil bare and subject to erosion, weeds are usually the first plants to move in and cover it. Far better a patch of weeds than an unsightly area of eroded soil. Man can control weeds but he cannot make soil. When unproductive fields are abandoned or other soil left bare the first plants to cover it are usually annual weeds. These are followed by perennial weeds which, in turn, ultimately are succeeded by the native vegetation of the region.

Pastures on native grassland are frequently overgrazed today, as in past centuries, to the extent that palatable plants become seriously depleted while unpalatable weeds such as pasture sage, broomweed, etc., increase in density and size. When asked how to kill these pasture weeds I always advise the removal of the cause first. In a way those weeds are protectors of the pasture. By their abundance they indicate the fact of overgrazing. They aid the recovery of native grasses by holding snow and reducing wind and water erosion. Ultimately they revert to their ncrmal position as a minor component of the native vegetation. Good husbandry will keep weeds under control as well as provide the farmer with a fair return from the land under his care.

It is well to be mindful of the probability that there will always be weeds. Man is continually disturbing the land surface, attempting to grow plants of his own choice in areas where other plants normally occur. The latter he calls weeds. In many instances those weeds are beneficial to him. Before destroying them he should stop to consider why they are present and, if possible, first remove the causes. Weeds, as I have indicated, are often nature's method cf correcting man's mistakes.

\title{
Snowy Plover Taken in Saskatchewan
}

\author{
by Douglas E. Wade, Regina
}

On May 31, 1964, a Snowy Plover (Charadrius alexandrinus) was discovered by my wife, Dorothy R. Wade, at Buck Lake, 18 miles south of Regina. Later the same day, at our request, the plover was collected by Elmer Fox of Regina. Robert W. Nero, ornithologist on the Regina Campus of the University of Saskatchewan, who prepared the specimen (a male) as a study skin, submitted it for subspecific determination to W. Earl Godfrey, Acting Chief Zoologist, National Museum of Canada, who identified it as the western race of Snowy Plover, Charadrius alexandrinus nivosus (Cassin). This race is confined largely to the Pacific coast from southern Washington to southern Lower California and inland from northern Utah and Kansas south to New Mexico and northern Texas. An eastern race, C. a. tenuirostris (Lawrence), is found in the Gulf States from Florida to Texas and in Cuba and other islands.

The Snowy Plover has been collected but twice previously in Canada; a specimen was taken in Toronto, Ontario, May, 1880, and again in the same city in July, 1897 (Bent, 1929 ); both have been assigned to the eastern race (A.O.U., 1957). The casual or accidental records for the western race include Wyoming and Nebrask'a (A.O.U., 1957), but Peterson (1961) includes Montana and omits Nebraska. Its occurrence in Saskatchewan must also be regarded as accidental.

Buck Lake, where the Snowy Plover was found, has been one of our favorite birding areas during the past four years. Not one of our trips there has been disappointing. We think of Buck Lake as a "bald" lake cn "bald prairie", although the treeless plains are practically all wheat fields with some farm buildings and tree wind-breaks nearby to the west and the southwest. Here is a neat, clean-cut prairie pothole lake. As you drive down the road you don't see the lake until you are almost into the depression. The lake is circular, shallow and muddy-looking; it and the exposed mud beach that growis quite wide during drouthy spells have very little marsh or aquatic 